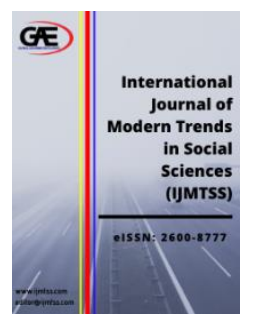

\author{
INTERNATIONAL JOURNAL OF \\ MODERN TRENDS IN \\ SOCIAL SCIENCES \\ (IJMTSS) \\ www.ijmtss.com
}

\title{
EMPOWERING THE LEARNING INSTITUTIONS IN MALAYSIA THROUGH WAQF AND ENDOWMENT: MEASURING THE LEVEL OF KNOWLEDGE AND AWARENESS OF ITS'COMMUNITY
}

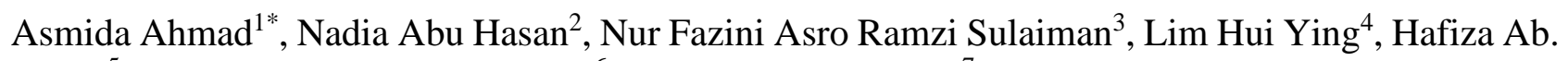
Razak $^{5}$, Muhammad Nor Abdurrahim ${ }^{6}$, Yusnita Mohd. Yusof ${ }^{7}$

1 Faculty of Law, Multimedia University, Malaysia

Email: asmida.ahmad@mmu.edu,my

2 Faculty of Law, Multimedia University, Malaysia

Email: nadia.abuhasan@mmu.edu.my

3 Faculty of Law, Multimedia University, Malaysia

Email: fazini.ramzi@mmu.edu.my

4 Faculty of Law, Multimedia University, Malaysia

Email: 1161101734@student.mmu.edu.my

5 Faculty of Law, Multimedia University, Malaysia

Email: hafiza.razak@mmu.edu.my

6 Faculty of Law, Multimedia University, Malaysia

Email: muhammad.abdurrahim@mmu.edu.my

7 Faculty of Law, Multimedia University, Malaysia

Email: yusnita.yusof@mmu.edu.my

* Corresponding Author

\section{Article Info:}

\section{Article history:}

Received date: 23.03 .2020

Revised date: 07.06 .2020

Accepted date: 23.11 .2020

Published date: 03.12.2020

\section{To cite this document:}

Ahmad, A., Hasan, N. A., Sulaiman, N F. A. R., Lim, H. Y., Ab.Razak, H., Abdurrahim, M. N., \& Yusof, Y. M.. (2020). Empowering The Learning Institutions in Malaysia Through Waqf and Endowment: Measuring

\begin{abstract}
:
Waqf and Endowment in education are two bodies that delivered charitable services for the education community into areas including social welfare, research, infrastructure development, and general well-being at learning institutions. However, in spite of playing an applaudable role in educational institutions, the experience of waqf and endowment in learning institutions in Malaysia has been evidently opposed to the experience in the West. The objective of the research is to seek the level of knowledge and awareness among the community in the learning institutions in Malaysia on waqf and endowment. The study of the research will focus on the survey that has been conducted at selected higher learning institutions and a discussion on factors that contribute to the level of knowledge and awareness of the matter. Hence, the research will also provide solutions and suggestions for improvement in order to maintain good practice and governance as well as its challenges in waqf and endowment at learning institutions. It is hoped that this research will
\end{abstract}


The Level of Knowledge and help to provide suggestions to enhance the development of the education Awareness of Its' Community. system as well as the development of the economy in Malaysia. International Journal of Modern Trends in Social Sciences, 3 (14), 84101.

DOI: $10.35631 /$ IJMTSS.314008

This work is licensed under CC BY 4.0

\section{Keywords:}

Waqf, Endowment, Education, Awareness, Good Governance

\section{Definition and Concept of Waqf and Endowment}

Waqf is an act of philanthropy; a term which derived from Arabic language that can be loosely understood as stopping, withholding, restraining or standing still. According to Dr Wahbah Zuhayli, al-waqf which have similar connotation with the term al-habas can literally means prevention from dealing. ${ }^{1}$ As for al-Shawkani, waqf is retaining ownership of property in Allah's cause for the needy and the wayfarer (in the cause of Allah) wherein the benefit of the property is spent by these people whereas the original property remains under the possession of the founder (al-waqif). ${ }^{2}$

Classical jurists have employed different definition of waqf from which they form their rulings on waqf. According to Abu Hanifah, the founder of Hanafi's school of thought, for instance, it is the detention of a thing in a way that the proprietor's right in the thing remains and the benefit of the thing shall go to some charitable purposes. ${ }^{3}$ However, according to al-Shafi'i, Malik and the two disciples of Abu Hanifah i.e. Abu Yusuf and Muhammad, waqf defined as the end of the appropriator's ownership in a thing dedicated and the detention of the thing in the ownership of Allah in such a manner that its profit or usufruct to be used for the good of mankind from beginning to the end. ${ }^{4}$

In brief, as highlighted by Jamal J. Nasir, waqf is defined as perpetual dedication of a property by a Muslim for charitable or religious purpose in a way that the proprietor's right is extinct; or for purposes set by the founder of waqf during his lifetime and after his demise or the founder's descendants and on their extinction. ${ }^{5}$

Waqf is an instrument which allows the owner of a property to benevolently transfer his right in that property to other without consideration. However, under Islamic jurisprudence, waqf does not provide for a complete ownership as it is a type of ownership by usufruct which allows others to enjoy the benefit of the property without having ownership over the property. ${ }^{6}$ Hence, it is a philanthropic act for the benefit of others.

\footnotetext{
${ }^{1}$ Wahbah Zuhayli, Al-Fiqh al-Islami wa Adillatuhu, v.8, 1985, Dar al-Fikr, Damascus, Syria, p. 153.

2 Muhammad bin Ali bin Muhammad al-Shawkani, Nailul Awthar Syarah Muntaqa al-Akhbar, v. 6, Final Edition, n.d., Mustafa al-Babi al-Halabi wa Awladuh, Egypt. p.24.

${ }^{3}$ Ibn Abidin, Muhammad Amin, Raddu al Mukhtar 'ala al Durri al Mukhtar Sharh Tanwir al Absar, v. 6, 2003, Dar 'Alim Kutub, Riyadh. p.519.

${ }^{4}$ Wahbah Zuhayli, Ibid, , p.154.

${ }^{5}$ Jamal J. Nasir, The Islamic Law of Personal Status, $2^{\text {nd }}$ Edition, 1990, Graham \& Trotman, London. p.274.

${ }^{6}$ Mustafa Ahmad al-Zarqa, al-Madkhalu al-Fiqhiyu al-'Am, Vol. 1, 1998, Dar al-Qalam, Damascus. p. 350.

Copyright $\odot$ GLOBAL ACADEMIC EXCELLENCE (M) SDN BHD - All rights reserved
} 


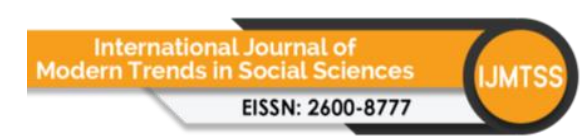

Volume 3 Issue 14 (December 2020) PP. 84-101

DOI 10.35631/IJMTSS.314008

The practice of waqf is recognized in Islam and considered as a commendable (mandub) practice. ${ }^{7}$ This can be shown through various express and implied authorities. Although in Quran, the term waqf is not specifically used to denotes act of benevolence or endowment, however there are clear commandments on giving charity and being generous. For instance, Allah says in the Holy Quran: "By no means shall you attain Al-Birr (piety, righteousness, etc., it means here Allah's Reward, i.e. Paradise), unless you spend (in Allah's Cause) of that which you love; and whatever of good you spend, Allah knows it well"8. Dr Wahbah Zuhayli when commenting on this verse had cited a Tradition narrated by Anas bin Malik regarding Abu Talha al-Ansari and his charity. He had the largest number of date palm trees and gardens, and the most beloved property to him was Bairuha garden which was standing opposite of Masjidin Nabawi. The Prophet used to enter the garden and drink of its good water. When the verse from Ali-Imran 92 was revealed Abu Talha got up and said: "O Messenger of Allah, Allah says: "By no means shall you attain righteousness unless you spend (in charity) of that which you love.." and the most beloved of my property to me is the Bairuha garden, so I give it as a charitable gift in Allah's Cause and hope to receive good out of it, and to have it stored for me with Allah. Dear Prophet! Dispose it of (i.e. utilize it) in the way as Allah orders you to dispose." Upon hearing this the Prophet said: "Good! That is a fruitful property! That is a fruitful property! I have heard what you have said and I think that you should distribute that (garden) amongst your relatives." Then Abu Talha distributed that garden amongst his relatives and his cousins. ${ }^{9}$

In one of the Tradition of Prophet Muhammad (p.b.u.h) reported by Abu Hurairah, the Messenger of Allah had said: "When a man dies, his deeds come to an end except three, recurring charity, or knowledge by which people benefit, or a pious son who always prays for him (for the deceased)."10 Al-Shawkani in commenting this Tradition stated that recurring charity (sadaqah jariah) in this Tradition refers to waqf as the jurists have interpreted as such. ${ }^{11}$

In another notable Tradition as narrated by Ibn Umar it was recorded that Umar ibn Khattab have lands in Khaibar and he have consulted the Prophet on how he should deal with the lands. The Prophet (p.b.u.h) replied: "If you want, you can give the land as endowment and its proceeds in charity." 12 From this hadith, the jurists have ruled the legality of endowing one's property as waqf for the purpose of charity. ${ }^{13}$

Conceptually, according jurists, there are pillars that need to be satisfied in order to establish a valid waqf. Although according to the Hanafi's school, the only requirement is that there must be an intentional pronouncement on the part of the founder (al-waqif) to endow his property, yet majority jurists laid down several requirements namely: a founder or creator of waqf (alwaqif), subject matter of waqf (al-mawquf), beneficiary of waqf (al-mawquf 'alaihi) and stipulation of waqf (sighah). ${ }^{14}$ The founder of waqf (al-waqif) must be someone who own a property and is capable of dealing with the property in his own capacity. He must be generally sane, a person of full age, free man and attained sufficient maturity. ${ }^{15}$

\footnotetext{
${ }^{7}$ Abdul Karim Zaidan, al-Mufassal fi Ahkam al-Marah wa al-Bait al-Muslim fi al-Syari'at al-Islamiyah, v.10, 1993, Muassasah al-Risalah, Beirut, Syria. p. 420.

${ }^{8}$ Surah Ali-Imran, 3:92.

${ }^{9}$ Wahbah Zuhayli, Tafsir al-Munir, v. 2, 2003, Dar al-Fikr, Damascus. p.319

${ }^{10}$ Sahih Muslim, Book 25, Hadith 20.

${ }_{11}$ Al-Shawkani, ibid.

12 Sahih Bukhari, Vol. 3, Book 50, Hadith 895

${ }^{13}$ Wahbah Zuhaily, Al-Wajiz fi al-Fiqh al-Islami, v. 3, 2006, Dar al-Fikr, Damascus. p.300.

${ }^{14}$ Wahabah Zuhaily, Ibid, p. 301.

${ }^{15}$ Abdul Karim Zaidan, supra, p.422.

Copyright $\odot$ GLOBAL ACADEMIC EXCELLENCE (M) SDN BHD - All rights reserved
} 


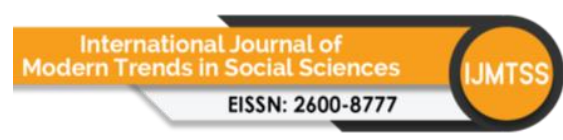

Volume 3 Issue 14 (December 2020) PP. 84-101 DOI 10.35631/IJMTSS.314008

To have a valid subject matter of waqf (al-mawquf), certain elements must be fulfilled as not all property can be accepted to be endowed by a founder. Although jurists agreed that waqf should be made of immovable property, the majority excluding Hanafi's school accepted that movable property can be made as waqf such as mosque equipment, garments, weapons, furniture, books etc. However, the movable property must be something that can be benefitted and enjoyed by other. ${ }^{16}$ Hence, to validate a property as waqf it must be something that is capable of being own and transferred; and it must be existed at the time when waqf is made. The property must also be able to be immediately be transferred when waqf is created. ${ }^{17}$ In recent days, validation of diverse properties to be accepted as subject matter of waqf has been ruled out and subsequently become a new trend in establishing waqf such as the use of cash waqf which in principal has been accepted especially by contemporary jurists. As some of classical jurists had decided on the applicability of cash money as waqf if proper and legitimate mechanism is adopted, the matter is now regarded as accepted and established. ${ }^{18}$

Types of waqf is mostly based on who is the beneficiary of waqf (al-mawquf 'alaihi) is concerned; a specified waqf such as waqf al-ahli or waqf al-zurri which is a type of waqf created for specified parties such as descendants or family members, individual or group. Another type is unspecified waqf such as waqf al-khairi which is established for benevolent or religious purpose. ${ }^{19}$ In this sense, it includes any beneficiary or any noble purpose such as for the use of mosque, health and education. Last but not least, the requirement of stipulation to create waqf by the founder must exist without which a waqf will be invalidated. The importance of this element is to identify the exact intention of the founder whether his act is a mere gift or waqf, thus making it as a crucial element. ${ }^{20}$

Waqf has played a significant role in elevating the social life of communities. According to Kuran, waqf is created when a proprietor endows his income-producing property in perpetuity for specific purpose of financing a designated social service. ${ }^{21}$ Hence, in Islam, waqf has been adapted in education for decades to fund and to help those in pursuit of knowledge especially in tertiary level. A successful model can be seen from the endowment established in Al-Azhar University, one of the oldest Islamic higher education institutions in Egypt. A fund was founded during the time of Muhammad Abduh, a Muslim reformist, who had suggested that students attending the university and overhead expenses for teacher and staff of the university to be funded from the endowment fund. ${ }^{22}$ In this present era, waqf has been used to provide education scholarship for the poor. ${ }^{23}$ It is highlighted that with perpetual, effective and

\footnotetext{
16 Wahbah Zuhayli, supra, p.163.

17 Sayid Sabiq, Fiqh al-Sunnah, 1983, vol. 3, Dar al-Fikr, Beirut, Lubnan. p.386.

${ }^{18}$ Wan Ariffin b. Wan Yon, Mohd Syahiran b. Abdul Latif \& Prof. Madya Dr. Hasan b. Bahrom, Mekanisme Wakaf: Gagasan Awal Terhadap Pembangunan dan Pembiayaan Pusat Penyelidikan dan Perkembangan Islam Borneo, 2008, Jurnal Pengurusan JAWHAR, Vol. 2, No. 2, p.63-86.

${ }^{19}$ Sayid Sabiq, ibid.

${ }^{20}$ Wan Ariffin, Mohd Syahiran \& Hassan, ibid.

${ }^{21}$ Timur Kuran, The Provision of Public Goods under Islamic Law: Origins, Impact, and Limitations of the Waqf System, Law \& Society Review, Vol. 35, No. 4 (2001), pp. 841-898

22 Abdul Halim bin Sunny, Dana Wakaf Untuk Pendidikan: Satu Tinjauan Awal, 2007, Jurnal Pengurusan JAWHAR, Vol. 1, No.2, p.33-44.

${ }^{23}$ Shaikh, Salman Ahmed ; Ismail, Abd. Ghafar ; Mohd. Shafiai, Muhammad Hakimi, Application Of Waqf For Social And Development Finance, ISRA International Journal of Islamic Finance. 2017 ; Vol. 9, No. 1. pp. 5-14.

Copyright $\odot$ GLOBAL ACADEMIC EXCELLENCE (M) SDN BHD - All rights reserved
} 
resourceful funding for education through the institution of waqf it is possible to improve the socio-economic mobility of the society and income-earning prospective of the beneficiaries. ${ }^{24}$

Meantime, an endowment in education represent money or other financial assets that are donated to universities or colleges and are meant to be invested to grow the principal and provide additional income for future investing and expenditures. Typically, endowment funds follow a fairly strict set of long-term guidelines dictating the asset allocation that will yield the targeted return without taking on too much risk. Most endowments have guidelines stating how much of each year's investment income can be spent. Endowment donors can sometimes restrict how the universities or colleges spend this money with an investment policy statement. For example, donors can decide to use a portion of an endowment's scheduled income on a merit-based or need-based scholarship. Another standard restrictive use of an endowment's income is to provide funding for endowed professorships, which are used to attract world-class educators. Other than these restrictions, universities can use the rest of the allotted spending amount as standard income. Decisions about whether it should be spent on hiring professors, upgrading/repairing facilities or funding more scholarships is left up to university/colleges administrators. An endowment's investment income can also significantly lower tuition costs for students.

\section{Objective and Research Methodology}

The objective of this paper is to seek the level of knowledge and awareness of the community in learning institutions on waqf and endowment. With an increase of costs at the higher education institutions, access to education can be expensive to the unfortunate. The paper expects alternatives solution in terms of financial assistance to assist the unfortunate as well as to ensure that a proper distribution of waqf and endowment is carried out. This will encourage the society at large, particularly to the stakeholders to invest more to the established and known educational financial aid.

The research of the paper is conducted by surveys by questionnaires to discover the level of knowledge and awareness of the community on waqf and endowment. From the findings, the paper will then identify the factors that contributes to it and will suggest better solutions to improve the issue. The discussion in this paper is based on literature review to find and suggest solutions that can fit to the system of financial aid at the higher learning institutions in Malaysia.

\section{Problem Statement and Limitation}

While there are a lot of emphasis on the role, function and how Educational Waqf and Endowment benefit the community, regrettably, awareness in society are still below the level of consciousness. The knowledge of the public on waqf is shallow and it has yet to become part of issue to be focused on by the society ${ }^{25}$. Likewise, lack of networking with the community such as alumni also led to low level of awareness on waqf and endowment. Thus, in order to ensure this behavior can be continuous, there is a need to identify the factors that contributes to it.

\footnotetext{
${ }^{24} \mathrm{Ibid}$

${ }^{25}$ Suziana Mohamed Nor \& Romzie Rosman, Cabaran Dalam Melaksanakan Wakaf Pendidikan Bagi Institusi Pengajian Tinggi Di Malaysia, e-Proceeding of the 4th International Conference on Masjid, Zakat and Waqf Management 2017 (IMAF2017), (e-ISBN 978-967-13087-3-8). 4th \& 5th December 2017, Bangi, Selangor, MALAYSIA

Copyright $\odot$ GLOBAL ACADEMIC EXCELLENCE (M) SDN BHD - All rights reserved
} 


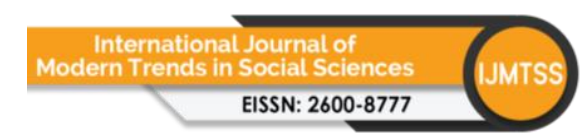

Volume 3 Issue 14 (December 2020) PP. 84-101

DOI 10.35631/IJMTSS.314008

As this study explores communities' awareness of educational waqf and endowment, there is limitation which can be improved in next study as the sample of this study is concentrated on respondents aged between 17 to 22 years old. Hence, the present study should be replicated to community in public or in whole Malaysia. The sample is taken from survey done at selected universities in Selangor and Melaka.

\section{Development of Waqf and Endowment in Education in Malaysia}

Education is a continuous activity process which comprise of the elements of teaching, training, guidance, and leadership with main focus of disseminating various disciplines of knowledge, religious and cultural values and useful skills from one generation to another or by an individual to another. Waqf and endowment is so closely related to education in Malaysia since the institution of educational waqf is established or built using property endowed by Muslims.

Historically, in Malaysia waqf for education began with institutions of traditional religious education, such as Sekolah Agama Rakyat or SAR (People's Religious School), Sekolah Agama Negeri or SAN (State Religious School), madrasah and pondok. In the practice of traditional Islamic education in Malaysia, Muslims endow their land to build religious schools. Then endowment was extended to surrendering their property and donation of money and kinds to build accommodation and facilities for teachers and students in the interest of education.

It is found out that funding of education through the Waqf instrument could help reducing the problems of school dropout and lagging behind among Muslim-Malay children caused by poverty. There are four factors contributing to the success of waqf implementation for education, that are, society's awareness, demographic situation, i.e. a high Muslim population, stable Muslim economy and professional and efficient governance ${ }^{26}$.

Generally, in waqf for traditional education, waqf assets take the form of lands, houses, mosques, buildings, books and so on. Lots of primary and secondary schools - be it religious or vocational-based school, all over Malaysia have benefitted from Waqf. Among the schools established in the middle of 20th century through the concept of waqf in Malaysia are Kolej Islam Malaya in Klang, Selangor, Maahad Mahmud in Kedah and Maahad Al-Mashoor AlIslami in Penang. Currently, waqf is increasingly utilized not only for the purpose of providing education at pondok, madrasah and book contributions in the name of traditional education system but has extended to providing education at institutions of higher education. Since 2016, Malaysian public universities have started to give more attention to the practice of Waqf. YB Dato' Seri Idris bin Jusoh, the Minister of Higher Education at that time, had proposed all public universities to establish Waqf funds ${ }^{27}$ in order to ensure public universities' financial sustainability in the long run.

The essential factor leading to the establishment of Waqf institutions in 2016 by public universities is due to government's financial constraint. Malaysia has been spending lots of money in education sector since its Independence in 1957. In 2015 alone, the government had

\footnotetext{
${ }^{26}$ Wan Kamal Mujani, Pelestarian Institusi Wakaf untuk Memperkasa Pendidikan Tinggi Negara (The Sustainability of Wakaf for Strengthening Institutions of Higher Education), Europen Journal of Multidisciplinary Studies, 2014, Vol. 5, p. 455-461

${ }^{27}$ Siti Mashitoh, Asmak \& Azizi, Pembentukan Institusi Pengajian Tinggi Berteraskan Wakaf Di Malaysia: Cadangan Model Pelaksanaannya, Jurnal Syariah: Vol. 26 No. 1, 2018, p. 1-22

Copyright $\odot$ GLOBAL ACADEMIC EXCELLENCE (M) SDN BHD - All rights reserved
} 
allocated RM15.78 billion (20.8 percent of the total budget) to the Ministry of Higher Education Malaysia. However, the total budget had been reduced in 2016 to RM13.37 billion ${ }^{28}$.

In addition to that, cost of education such as tuition fees, payrolls as well as university's assets maintenance have been steadily increasing from time to time ${ }^{29}$. Thus, the decreasing budget allocation and increasing cost of education has prompted the steps to look for alternatives to ensure financial stability of public universities in the future.

Since then, majority of public and private Universities in Malaysia are rigorously giving serious attention to the waqf in the sphere of education. It is then realized that waqf could be an instrument for higher education institution to generate income and indirectly could overcome over reliance of the public on the government educational funds.

At the same time, Malaysians especially the Muslims community has increasingly believing on the view of the roles Waqf from traditional-religious mechanism towards the more widely functional third economic sector mechanism ${ }^{30}$. They develop a confidence that the third economic sector - also known as voluntary sector, empowered by philanthropy activism such as Waqf and endowment could become equally important forces beside the public and private sectors. As such, the establishment of Waqf institutions in public universities is well-received and supported by most Malaysians. International Islamic University Malaysia (IIUM) is the pioneer to this by establishing their own IIUM Endowment Fund in 1999. It was a visionary approach taken by the management of IIUM in order to give financial support to its students, especially the international students as well as to lessen the financial dependency of the students on the government.

This step has been followed by other universities, public and private, from time to time. In 2016, the Ministry of Higher Education has acknowledged the need for all public universities to have their own financial supports and lessen financial dependency on the government. University Transformation Programme or UTP was launched and one of the focuses is financial stability by enhancing university income generation, endowment and waqf.

As of 2020, most of public and private universities in Malaysia have already implemented waqf in their education institutions. They have established their own Waqf administration institution in order to manage and coordinate Waqf and endowment activities. Among the aims of their establishments are for the purpose of receiving assets, cash, shares and financial assets from within the country and overseas to be used to finance scholarships, loans and transactions to expand the fund such as investment activities.

Since the Malaysian Government is fully aware that education is important for the future development of Malaysia, hence, National Higher Education Fund Corporation, or better known as PTPTN, was established under the National Higher Education Fund Corporation

\footnotetext{
${ }^{28}$ Mokthar Ismail , Fuadah Johari \& Mohd. Nazri Mohd Noor, Waqf Institutions In Public Universities Of Malaysia: Background, Governance, Organizational Structure, Objectives And Activities, E-Proceeding International Conference on Economics, Entrepreneurship and Management (ICEEM 2019), p. 1-9

${ }^{29}$ Azri Ahmad, Syarqawi \& Mohd Asyran, Education Development Through Waqf, 3rd International Conference on Islam and Higher Education (3rd ICIHE), 1st - 2 nd October 2012, Pahang, p. 1-22

${ }^{30}$ Salehuddin Md Dahlan \& Nor Asiah Mohamad, Waqf Literatures From Malaysia : 60 Years After Independence, Global Waqf Conference at Premiere Hotel, Pekanbaru, Riau, Indonesia on 17 th October 2017
} 
1997 (Act 566) which became effective on 1st July 1997 to provide and manage a loan scheme to Malaysian undergraduates who pursue higher education at public or private universities in Malaysia. Even though this is not established on the concept of waqf, but it has given a financial assistance and support to many Malaysian in pursuing their tertiary studies.

Waqf itself is not an easy concept since it is religious in nature and therefore, its principles must be clearly understood. In Malaysian legal context, the legal framework and its strict rules under Islamic law make it more complex for universities in Malaysia to implement. State Islamic Religious Council for example is the main authority who has an exclusive power on matters concerning waqf. In this regard, a MAIN (State Islamic Religious Council) is the sole trustee of waqf in each state. Therefore, public universities must acquire the permission from MAIN to be a waqf administrator (Nazir), so university's administrator must follow this requirement in order to implement waqf in each particular university ${ }^{31}$.

As a waqf administrator, public universities are empowered by MAIN to establish a sustainable infrastructure which will allow them to collect, raise, use, manage, invest, and develop waqf funds, as well as distribute waqf proceeds as agreed in the MoA between the public university and the respective MAIN. It is also important to understand the core principles of Waqf before transforming it into the university's income generation ecosystem. The power of state authority in issues relating to waqf is contradicting to the higher education activities that fall within the ambit of federal matters shall be properly addressed.

Generally, it is not easy to generate the Muslim Ummah's wealth through Waqf, Zakah and other philanthropy mechanism. Waqf institutions in public universities are required not only to receive Waqf donation, manage Waqf asset and distribute the benefits. They are also required to expand the assets and its benefits for the sake of Ummah. This is such a complicated and difficult duty. Universities must use all of their expertise, tools, strategies to ensure the growth of waqf and that the waqf is Syariah compliance. This can only be achieved by having a proper waqf office and governance structure at the university. Waqf administrators can adopt various strategies to manage waqf assets. The benefits given to waqf beneficiaries can be in various forms, including scholarships and other academic financial support, grants for research, academic or professorial chairs, traveling allowances for conferences as well as sponsorships for academic and research programme.

Even though waqf for education in Malaysia is still at the infant stage, it still has a positive progress. Waqf should be implemented in Malaysian higher education institution in order to maintain the progress of the institution itself. The Ummah has warmly accepted and supported the establishment of Waqf institutions in public university by becoming endowers especially to the cash Waqf scheme. Even though waqf higher education in Malaysia is developing and getting a good support from the government especially from Ministry of Higher Education (MOHE), nonetheless, it is also exposed to many constraints and obstacles that should be taken into consideration.

Apart from that, measures to ensure continuous improvement particularly related to the sustainability of Waqf benefits distribution should be seriously considered. Among the factors

\footnotetext{
31 Nor Suziana \& Noor Inayah, Transformation of the Role of Waqf in Malaysia, Advanced Science Letters 23(1):494$496 \cdot$ January 2017, p.1-4
} 


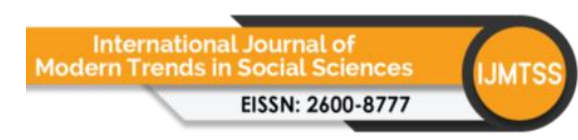

Volume 3 Issue 14 (December 2020) PP. 84-101

DOI 10.35631/IJMTSS.314008

leading to the success of public universities' Waqf institution is the institutions' ability to understand endowers' needs and constraints. Thus, institutions should be aware of the methods and mediums that may attract endowers to participate in specific Waqf scheme.

Looking at endowments institutions, its foundations and endowments have always been a significant source of funding for scholarships, professorships, academic programs, scientific researches, and other operational activities in universities. In many cases, a significant portion of universities' operating budget is financed through endowment fund ${ }^{32}$. The authors continued to discuss about the unique nature of endowment funds creates the need to preserve the principal amount in the long-term. Incidentally, different universities apply distinctive approaches in order to achieve endowment funds' investment targets that are parallel with their institutions' objectives. This study explained more on management of the endowment and waqf at the end but did not examine the awareness of community regarding the existence of the endowment.

Siti Mashitah Mahmood and Amsak Ab Rahman in their article, Financing universities through waqf, pious endowment: is it possible? ${ }^{33}$ stated that the Western world has many universities that were established under the concept of endowment. The most famous examples are the universities of Oxford and Cambridge in the UK and the universities of Harvard and Yale in the USA. In fact, the power of compassionate giving in endowment for higher education has convinced the UK Government. The concept of an endowment-based university has also been the practice of the Oxford and Cambridge colleges, popularly referred to as Oxbridge, where the support of the colleges comes from charitable giving. The colleges have been sustained by benefactions since they were founded. The head of the college and its appointed fellows are the responsible parties for the pious work, and they make an effort to fulfil the objective of the charity. They act like trustees but are also the beneficiaries of the foundation. The source of income for the establishment and survival of a university are well promoted for example Islamic Endowment Fund (IEF) of the IIUM also received waqf donations from some international guests visiting the university. At the end, the study suggested address the existing gap which has partly been filled by their research, in order to ensure the continuity of the previous successful implementation of waqf financing in higher educations in order to serve to unify past civilizations with modern practices. The study did not analysed the knowledge of the community regarding the function of the endowment in universities or any higher educations.

While Nor \& Rosman ${ }^{34}$ found out that the people were less well-informed because of the lack of understanding of the waqf and thus made the waqf government impossible. It was also due to the public's understanding of the role of waqf which in turn looked to immovable property as a waqf asset. Thus, the stakeholders need to give the people an understanding of the true concept of waqf. This study totally analysed on waqf itself and not compared it with endowment.

\footnotetext{
${ }^{32}$ Nazrol Kamil Mustaffa Kamil \& Mohamad Aslam Haneef, Investment Practices of Endowment Funds in Higher Education: Lessons for the Developing World, Book of International Symposium on Waqf and Higher Education (ISWHE 2016), ISBN: 978-983-44600-2-0, p. 137-146

${ }^{33}$ Siti Mashitoh Mahamood Asmak Ab Rahman, Financing universities through waqf, pious endowment: is it possible?, 2015. Humanomics, Vol. 31 Iss 4, p. 430 - 453

${ }^{34}$ Suziana Mohamed Nor \& Romzie Rosman, footnote 25.

Copyright $\odot$ GLOBAL ACADEMIC EXCELLENCE (M) SDN BHD - All rights reserved
} 
How much will we be able to learn from historical practices of education waqf as opposed to the practices of contemporary waqf for education as well as the practice of endowments in the west (and east)? Is there anything sacred in the term waqf itself or one could be open to the possibility of 'Islamic endowments'? This question was put up in the article of Funding of Higher Education in Malaysia- The Potential Role of Awqaf and Endowments. The author stated that not only is awareness and correct understanding of waqf still required as far as the regulators, recipient institutions and donors are concerned, getting agreement and some kind of consensus from all stakeholders is also a tall order. Trying to develop competent regulators and waqf managers as well as qualified mutawalli pose huge agendas in themselves. Having people who have the Islamic vision of an awqaf agenda and who are willing and able to make the necessary modifications to the legal and administrative policy framework and implementation manuals, is a must.

\section{Background of Survey and Findings}

The survey was conducted through online questionnaires to the respondents at selected universities in Malaysia. The findings were answered by a total of 331 respondents aged between 17 to 22 whom are currently studying at respective universities when the survey was conducted. The survey started with a very basic questions on gender, age and interest; to the understanding of waqf and endowment at their respective university. The discussion of the findings is divided into few phases; phase 1, is the level of awareness among the respondents on waqf and endowment. Phase 2 is the level of awareness of the respondents on the existence of the same subject as financial education aid at their respective university and followed phase 3 , the suggestion factors to the contributions of the respondent's level of awareness on the subject matter. Each finding is separated by waqf and endowment as different subject heading.

\section{Phase 1: Level of Awareness from Respondents on Waqf And Endowment}

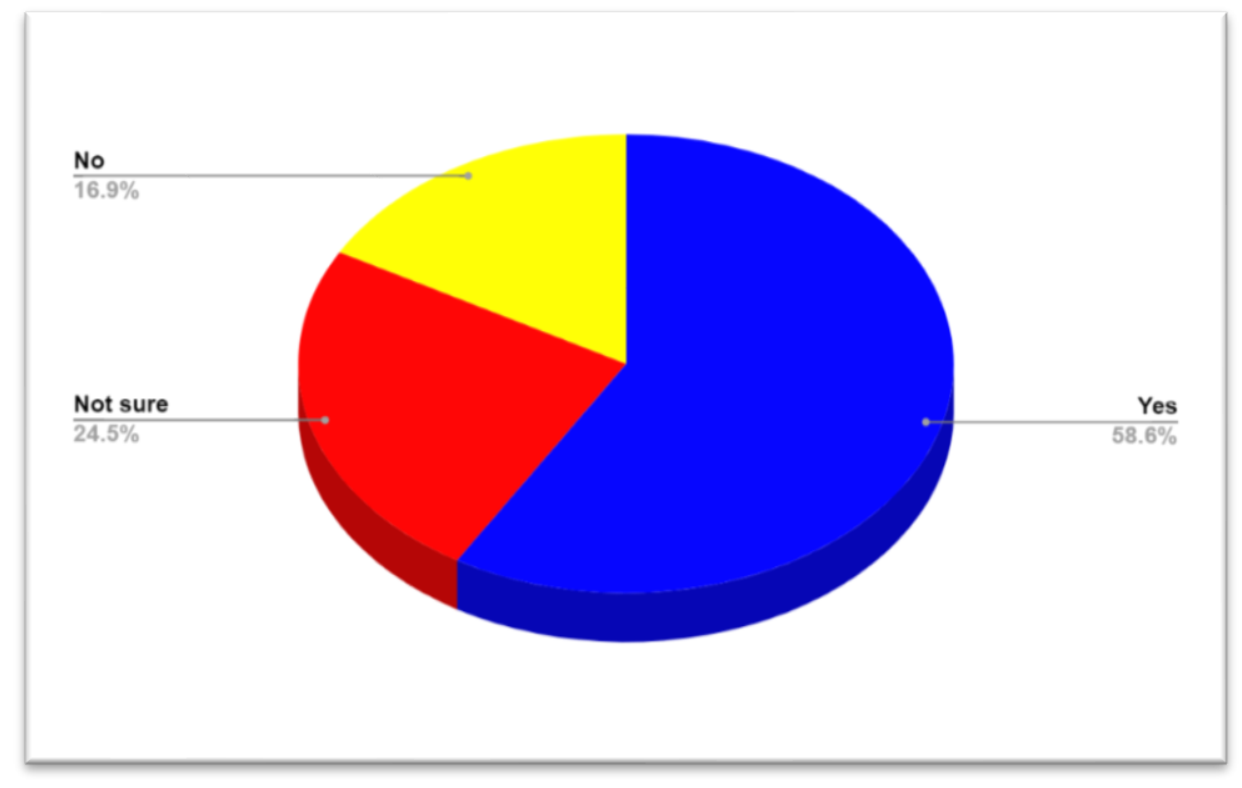

Figure 1.1: The Level of Awareness Among the Respondents on Waqf

The above is the finding of the level of awareness of respondents on waqf. Out from the total number, $58.6 \%$ knew on waqf followed by $24.5 \%$ whom are not sure what waqf is and $16.9 \%$ representing not knowing what waqf all is about. 


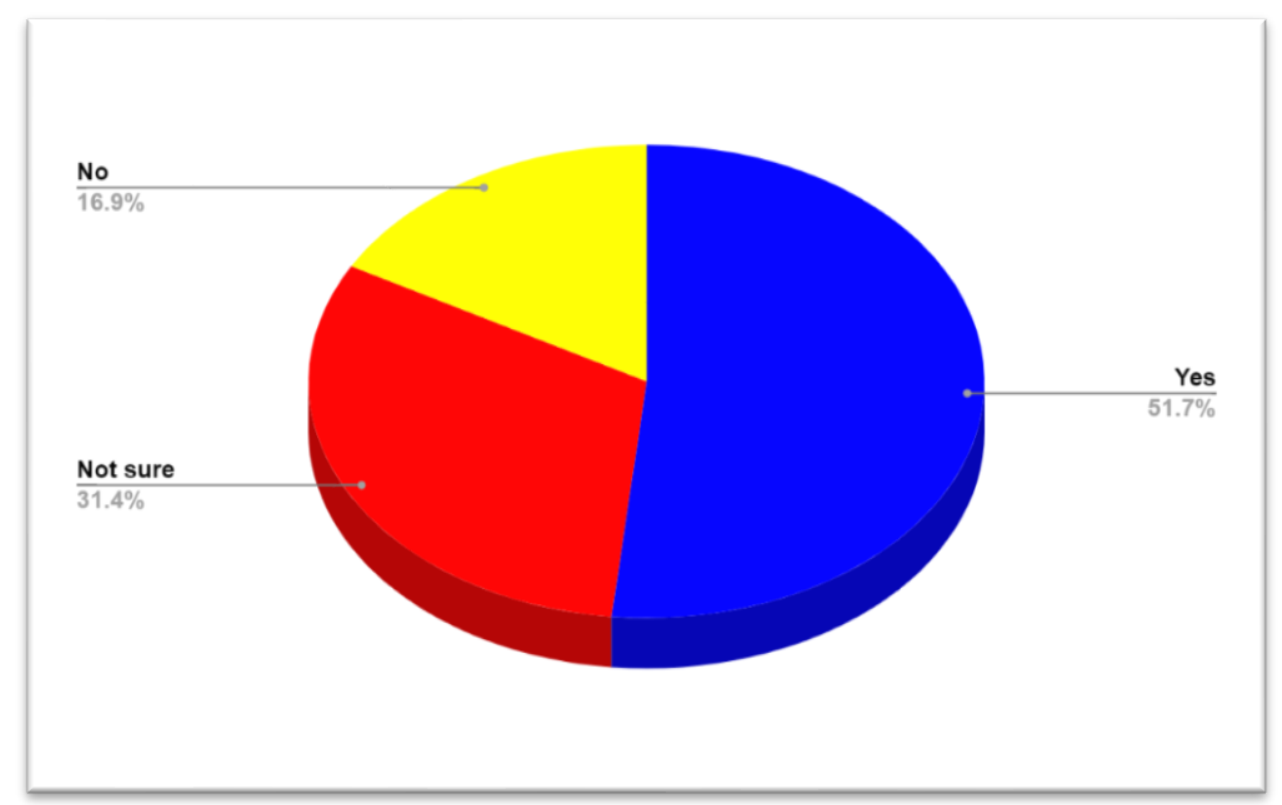

Figure 1.2: The Level of Awareness Among the Respondents on Endowment

Meanwhile, the above Figure 1.2 found out that the level of respondents knowing on endowment is $51.7 \%$ followed by a total of $31.4 \%$ of not sure what endowment is and another $16.9 \%$ have no idea what endowment all about.

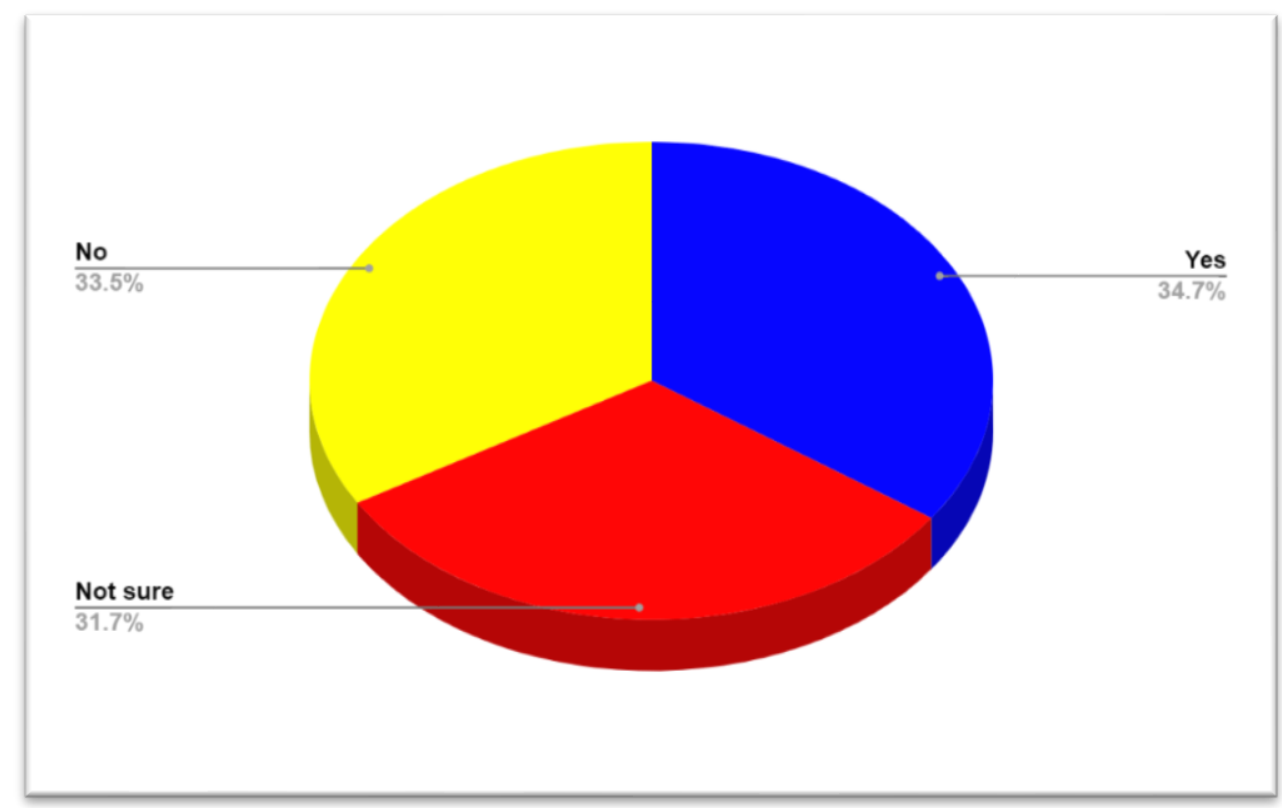

Figure 1.3: The Level of Awareness from Respondents on Waqf As Financial Education Aid

From the above, Figure 1.3 summed up that $34.7 \%$ has the awareness that waqf acts as a financial aid for education. However, $33.5 \%$ finds that waqf is not a financial education aid while another $31.7 \%$ is not sure. 


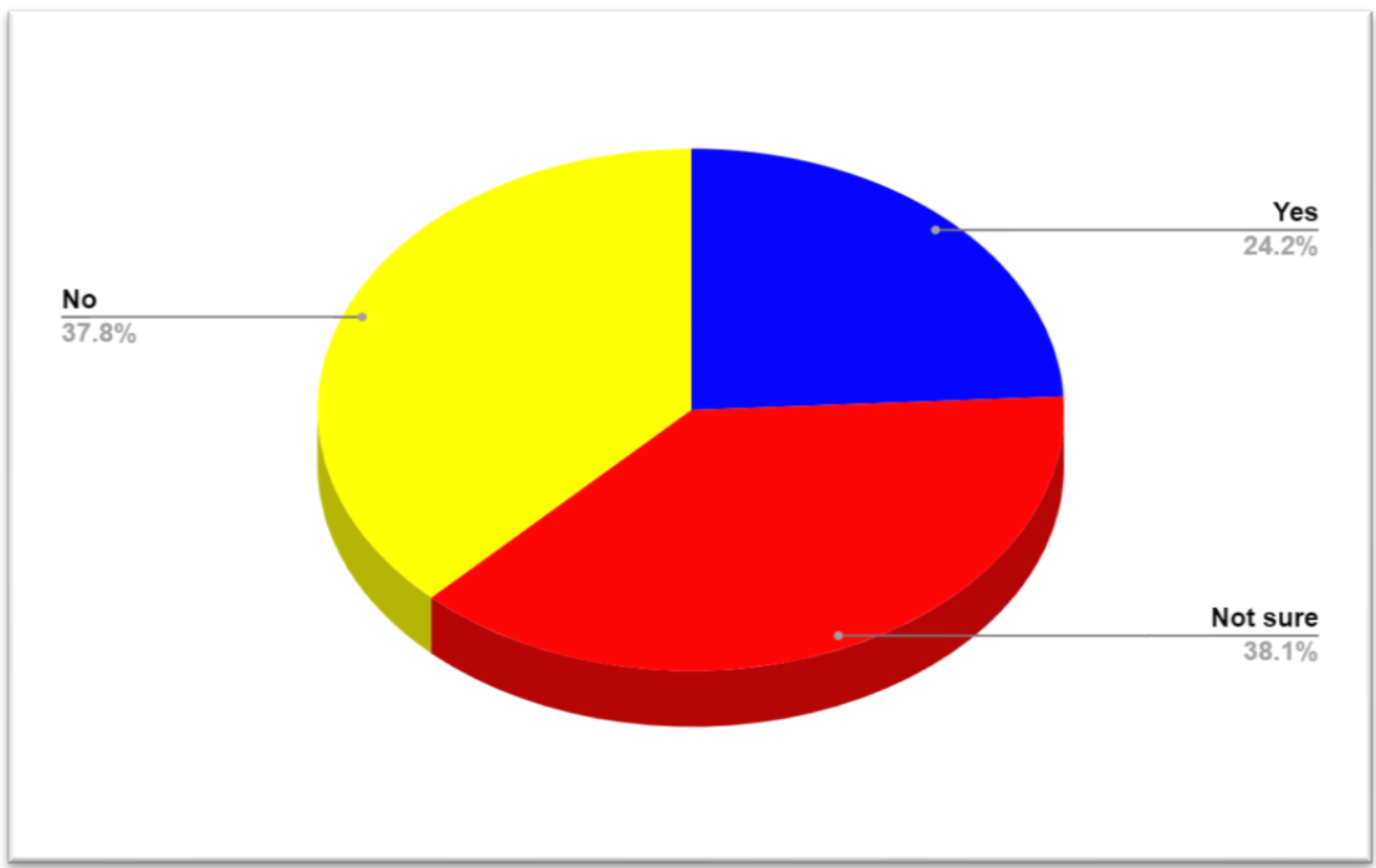

Figure 1.4: Awareness from Respondents on Endowment as Financial Education Aid

The above figure indicated that only $24.2 \%$ have the awareness that endowment is a financial aid for education. Meanwhile $38.1 \%$ have no knowledge that endowment is a financial source for education while the balance has no awareness on this.

\section{Summary of Phase 1}

The survey in phase 1 provide the level of awareness of the community being in this survey, the students themselves on waqf and endowment. From the survey, it is safely to state that, the awareness on the existence of Waqf is more compared to Endowment. However, it is still sad to know that there are still number of people who has no knowledge on what is Waqf and Endowment considering that the survey is conducted at university level. Phase 1 also indicates that, the awareness of the respondents i.e university's students on acknowledging that Waqf and Endowment is one of financial aid for education is very worrying. From the findings, we can conclude that about $65.2 \%$ have no awareness that Waqf is part of financial education aid while about $75.9 \%$ students being the respondents have no awareness that Endowment is part of financial education aid. 
Phase 2: Level of Awareness of The Existence of Waqf And Endowment at Their Respective Universities

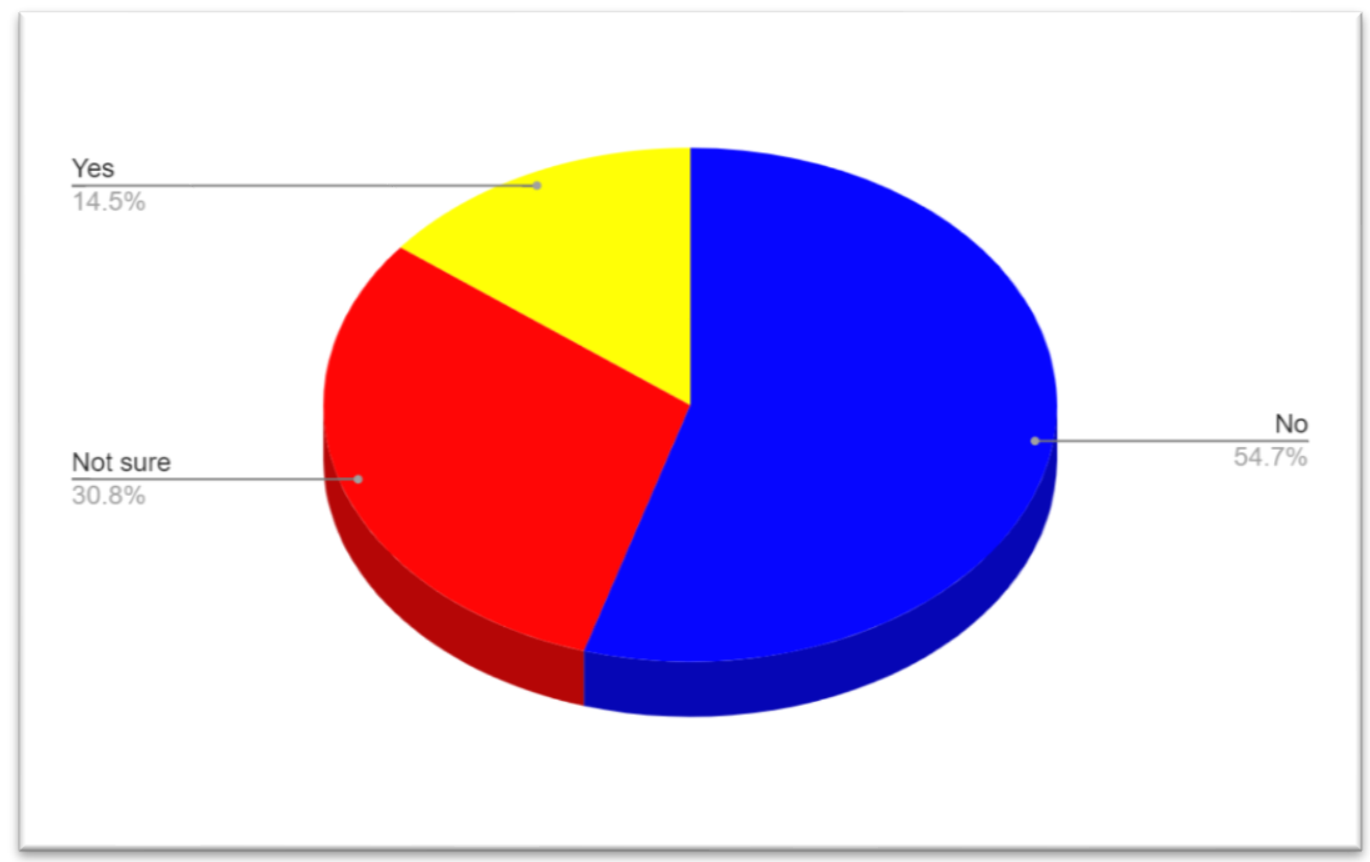

Figure 2.1: Awareness from Respondents on Existence of Waqf at Their Respective University

The above figure suggests that, $54.7 \%$ of the students do not aware on the existence of Waqf in their respective university. Only $14.5 \%$ of the students were aware of it and the balance are not sure.

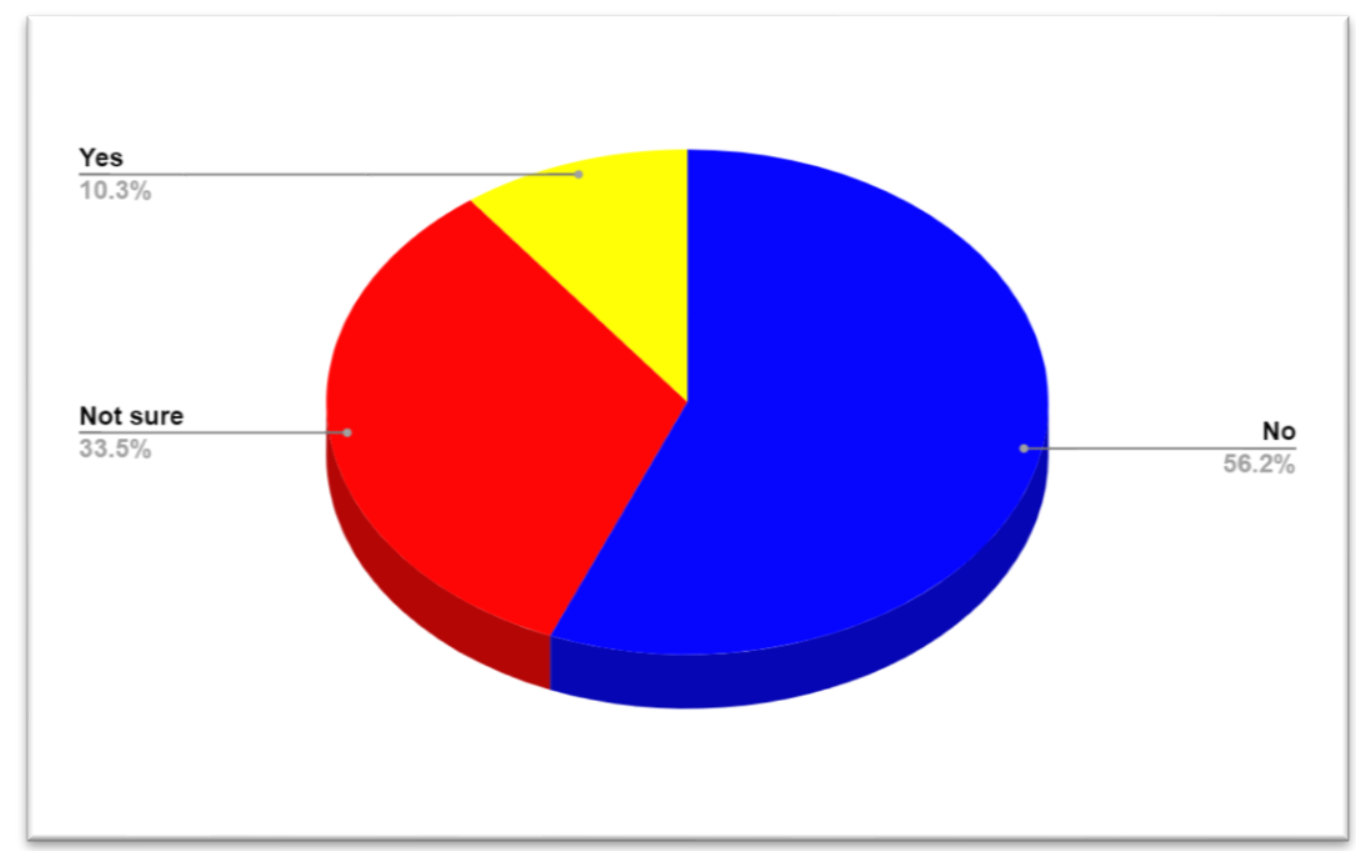

Figure 2.2: Awareness from Respondents on Existence of Endowment at Their Respective University 
From the above figure, $56.2 \%$ of the students do not aware on the existence of Endowment at their respective university while $33.5 \%$ are not sure whether Endowment fund exist at their university. Only $10.3 \%$ having the knowledge of the existence of Endowment fund at their university.

\section{Summary of Phase 2}

Findings at phase 2 involved the level of awareness of the students on alternative financial education aid at their respective university being Waqf and Endowment. Unfortunately, majority of the students have no knowledge the existence of alternative financial education aid which are Waqf and Endowment in their university. Phase 3 will look into suggestion factors that contributes to these low number of awareness.

\section{Phase 3: Suggestion Factors That Contributes to The Level of Awareness on Waqf and Endowment}
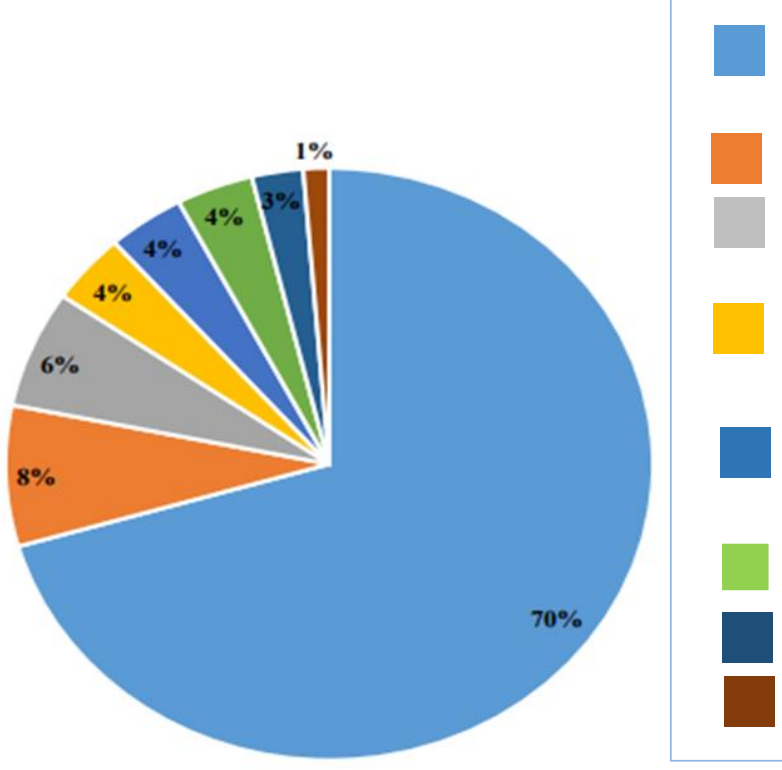

Lack of awareness on the existing of Waqf and Endowment in the University

Improvements are needed

Lack of awareness that Waqf and Endowment is an alternative financial education aid

Lack on the operation of management of University on Waqf and Endowment

Lack on the publicity on the outcome of Waqf and Endowment

Lack of confidence in the management

Lack of students' opinion

Strict formalities

\section{Figure 3.1: Suggestion on Factors to Contribute to The Awareness on Waqf And Endowment as Financial Education Aid}

Figure 3.1 is the respondent's view on suggestion of factors that contribute to the level of awareness of Waqf and Endowment as financial education aid. From the above figure, $70 \%$ of the respondents believe that lack of awareness on the existing of Waqf and Endowment in the University as being the most the contributory factor to low level of awareness from the students. $8 \%$ of the respondents believe that more improvements should be made to the Waqf and Endowment system. This is to ensure that the students are more aware on Waqf and Endowment that is provided at their University, while another $6 \%$ have no awareness that Waqf and Endowment is one of financial education sources at the higher learning education. In the meantime, suggested factors that being chosen by the respondents for low number of awareness from the students on the subject matter is lack on the operation of management of University 
on Waqf and Endowment lack of publicity on the outcome of Waqf and Endowment. Each factor equally shares $4 \%$ after being suggested by the respondents. $3 \%$ of the respondents believes that the management is lacking student's opinion while another $1 \%$ believes that strict formalities on application may be made the financial aid unknown to students.

\section{Summary of Phase 3}

The factors listed in Figure 3.1 is suggestions made that being chosen by the Respondents as factors that contribute to the low level of awareness by the students about Waqf and Endowment at their own University. The main factor which is lack of awareness on the existence of Waqf and Endowment has taken the major contributory factors to the low level of awareness. In another word, most of students do not even aware that Waqf and Endowment actually exist in their University and more as one of the financial aid in education.

\section{Discussion and Recommendation from Phase 1,2 and 3 Findings}

"If people see waqf from the limited perspective of life after death, the potential of waqf as a good practice and its benefits to the progress and prosperity of the Muslims, especially in facing the challenges of the new millennium, will not be achieved" (Harun, Abd Mutalib et al, 2016).

Based on a report by UNESCO (2009) which surveys 51 countries, the impact of the economic crisis towards the education system are in terms of cost sharing (tuition and other fees), costrecovery (different types of student loans) and financial diversification (income-generation and fund-raising $)^{35}$. The increasing in cost for education in Malaysia is skyrocketing. Education fees has been increasing aligned with the needs of the education structure system. What more, many has shared their concerns on the welfare of the students studying in Universities. It is very common to see students having their meals at mosque or queuing to have free meal at welfare shelters due to financial difficulties. Scholarships and education loans (PTPTN) seems cannot accommodate the increasing numbers of students each at the higher level each year. Malaysian government grant for education is more than double of that than other ASEAN countries. Ministry of Education is the ministry that often gets the highest amount of government budget allocation. Malaysia ranks 11th out of 50 countries for resources allocated for higher education under the Universities 21 ranking of national higher education systems. However, Malaysia is 39th in terms of output and impact on research, institutional excellence, and graduate employability.

Although the push of diversifying funding is proven to be successful overseas, Malaysia needs a different model of diversifying funding due to different political, economic and social landscape as compared to developed countries. Hence, alternative financial aid for education needs to be made known to the society in order to assist the future generation in claiming their rights in education. There is special attention devoted by the Ministry of Education through the introduction of the "UniTP Purple Book: Enhancing University Income Generation, Endowment \& Waqf', which highly encourages alternative financing and provides a guideline for HEIs to generate income through waqf and endowment, in order to achieve one of the ten shifts in the Malaysia Education Blueprint 2015-2025 (Higher Education).

\footnotetext{
${ }^{35}$ Abdul Razak, Che Embi et al. A Study On Sources Of Waqf Funds For Higher Education In Selected Countries, 2017, p. 113-128. 
Currently, the only legal requirement to establish waqf for universities is to acquire the permission from State Islamic Religious Council (SIRC). According to UPM, to establish waqf in HEI, an MoU should be signed by both Perbadanan Wakaf Selangor (PWS) and HEI. Prior to that, the MoU will be reviewed by the legal department of UPM before it is brought to Jawatankuasa Pengurusan Universiti and subsequently to Lembaga Pengarah Universiti in order to be approved. After that, it will be signed by PWS and UPM. However, the issue here is on the awareness of the students nor even the public at large on the existence of Waqf and Endowment as one of the financial aid for education. From the findings; Figure 1.3 and 1.4 had indicated the level of awareness from the students to see Waqf and Endowment as alternative financial education aid for them. The knowledge of the public on waqf is shallow and it has yet to become an issue to be focused on by the society. The understanding of Malaysians on waqf is limited as they believe that waqf is only limited to mosques and religious institutions etc. They also have some concerns regarding the permissibility of modern waqf e.g. cash waqf and waqf shares, thus showing less confidence towards the potentials of waqf in community development. Research has stated that only $20 \%$ of public universities' staff understand the concept of waqf when there were also even lecturers did not fully understand the differences between waqf and endowment. Some universities have misconceptions that endowment and waqf are the same. Hence, they named their waqf fund as endowments in order to escape the bureaucracy and procedures to establish waqf as well as to retain their power to administer the waqf.

One of the factors that contributes to the low awareness on the practice of waqf among university students is attributable to the lack of information provided to them. This is also proven at Figure 3.1 in this paper.

\section{Recommendations}

Awareness regarding the various forms of waqf, such as cash waqf, stock waqf, and waqf corporations is necessary for economic development and must be continued to encourage community participation in the development of waqf in Malaysia. In Selangor, PWS disseminates the importance of waqf in society through sermons and religious lectures in every mosque in Selangor and "Waqf Month". Social Media is will become the best platform to also publicise the existing of Waqf and Endowment and to educate the society to these alternative education aid. Research shows that the effects of radio advertising have stimulate public donations to waqf collection. The Muslims need to be told of the importance of diversifying their contribution under waqf as the scope of the usage of waqf property are wider compared to zakah and sadaqah which are applicable to the needy and poor in most cases. One important encouraging recent development in this field is the inclusion of waqf as an integral part of Islamic Financial Planning which is offered by a number of consultant agencies in Malaysia. It is hoped that more awareness programme will be organize in order to create awareness among the people of the wider meaning of waqaf and its importance.

A good reporting practice is one of the means for mutawalli to discharge his accountability to the waqf stakeholders. In other words, mutawalli's efficiency and effectiveness performance in managing the waqf assets could be evaluated through good financial reporting It consists relevant information in evaluating the financial performance and accountability of an organization, hence able to build public trust (International Integrated Reporting Committee, 2011) and attracts more donors. Hence, by showing a due diligence report on Waqf and Endowment management, the society will be more confident and acknowledge of the 
involvement of the donors to the funds. This will also boost the trust from the stakeholder as they can see that their investment is worth invested.

\section{References}

Al Quran Al Karim, Surah Ali-Imran, 3:92.

Abdul Halim bin Sunny, Dana Wakaf Untuk Pendidikan: Satu Tinjauan Awal, 2007, Jurnal Pengurusan JAWHAR, Vol. 1, N0.2, p.33-44.

Abdul Karim Zaidan, al-Mufassal fi Ahkam al-Marah wa al-Bait al-Muslim fi al-Syari'at alIslamiyah, v.10, 1993, Muassasah al-Risalah, Beirut, Syria. p. 420.

Abdul Razak, Che Embi et al. A Study On Sources Of Waqf Funds For Higher Education In Selected Countries, 2017, p. 113-128.

Azri Ahmad, Syarqawi \& Mohd Asyran, Education Development Through Waqf, 3rd International Conference on Islam and Higher Education (3rd ICIHE), 1st - 2 nd October 2012, Pahang, p. 1-22.

Ibn Abidin, Muhammad Amin, Raddu al Mukhtar 'ala al Durri al Mukhtar Sharh Tanwir al Absar, v. 6, 2003, Dar 'Alim Kutub, Riyadh. p.519.

Jamal J. Nasir, The Islamic Law of Personal Status, $2^{\text {nd }}$ Edition, 1990, Graham \& Trotman, London. p.274.

Mokthar Ismail, Fuadah Johari \& Mohd. Nazri Mohd Noor, Waqf Institutions In Public Universities Of Malaysia: Background, Governance, Organizational Structure, Objectives And Activities, E-Proceeding International Conference on Economics, Entrepreneurship and Management (ICEEM 2019), pp. 1-9

Muhammad bin Ali bin Muhammad al-Shawkani, Nailul Awthar Syarah Muntaqa al-Akhbar, v. 6, Final Edition, n.d., Mustafa al-Babi al-Halabi wa Awladuh, Egypt. p.24.

Mustafa Ahmad al-Zarqa, al-Madkhalu al-Fiqhiyu al-'Am, Vol. 1, 1998, Dar al-Qalam, Damascus. p. 350.

Nazrol Kamil Mustaffa Kamil \& Mohamad Aslam Haneef, Investment Practices of Endowment Funds in Higher Education: Lessons for the Developing World, Book of International Symposium on Waqf and Higher Education (ISWHE 2016), ISBN: 978-983-44600-20 p. 137-146.

Nor Suziana \& Noor Inayah, Transformation of the Role of Waqf in Malaysia, Advanced Science Letters 23(1):494-496 - January 2017, p.1-4.

Sahih Bukhari, Vol. 3, Book 50, Hadith 895.

Sahih Muslim, Book 25, Hadith 20.

Salehuddin Md Dahlan \& Nor Asiah Mohamad, Waqf Literatures From Malaysia : 60 Years After Independence, Global Waqf Conference at Premiere Hotel, Pekanbaru, Riau, Indonesia on 17 th October 2017.

Sayid Sabiq, Fiqh al-Sunnah, 1983, vol. 3, Dar al-Fikr, Beirut, Lubnan. p.386.

Shaikh, Salman Ahmed ; Ismail, Abd. Ghafar; Mohd. Shafiai, Muhammad Hakimi, Application Of Waqf For Social And Development Finance, ISRA International Journal of Islamic Finance. 2017 ; Vol. 9, No. 1. pp. 5-14.

Siti Mashitoh Mahamood Asmak Ab Rahman, Financing universities through waqf, pious endowment: is it possible?, 2015. Humanomics, Vol. 31 Iss 4 pp. $430-453$.

Siti Mashitoh, Asmak \& Azizi, Pembentukan Institusi Pengajian Tinggi Berteraskan Wakaf Di Malaysia: Cadangan Model Pelaksanaannya, Jurnal Syariah: Vol. 26 No. 1, 2018, p. 122.

Suziana Mohamed Nor \& Romzie Rosman, Cabaran Dalam Melaksanakan Wakaf Pendidikan Bagi Institusi Pengajian Tinggi Di Malaysia, e-Proceeding of the 4th International 
Conference on Masjid, Zakat and Waqf Management 2017 (IMAF-2017), (e-ISBN 978967-13087-3-8). 4th \& 5th December 2017, Bangi, Selangor, Malaysia.

Timur Kuran, The Provision of Public Goods under Islamic Law: Origins, Impact, and Limitations of the Waqf System, Law \& Society Review, Vol. 35, No. 4 (2001), p. 841898.

Wahbah Zuhayli, Al-Fiqh al-Islami wa Adillatuhu, v.8, 1985, Dar al-Fikr, Damascus, Syria, p. 153-154.

Wahbah Zuhayli, Tafsir al-Munir, v. 2, 2003, Dar al-Fikr, Damascus. p.319.

Wahbah Zuhaily, Al-Wajiz fi al-Fiqh al-Islami, v. 3, 2006, Dar al-Fikr, Damascus. p.300.

Wan Ariffin b. Wan Yon, Mohd Syahiran b. Abdul Latif \& Prof. Madya Dr. Hasan b. Bahrom, Mekanisme Wakaf: Gagasan Awal Terhadap Pembangunan dan Pembiayaan Pusat Penyelidikan dan Perkembangan Islam Borneo, 2008, Jurnal Pengurusan JAWHAR, Vol. 2, No. 2, p.63-86.

Wan Kamal Mujani, Pelestarian Institusi Wakaf untuk Memperkasa Pendidikan Tinggi Negara (The Sustainability of Wakaf for Strengthening Institutions of Higher Education), Europen Journal of Multidisciplinary Studies, 2014, Vol. 5, p. 455-461. 